\title{
Diagnosis Dini Autis Pada Anak Menggunakan Metode Inferensi Fuzzy Mamdani
}

\author{
Helen Sastypratiwi ${ }^{\# 1}$, Anggi Srimurdianto Sukamto ${ }^{\# 2}$ \\ \#Program Studi Teknik Informatika Fakultas Teknik Universitas Tanjungpura \\ 1helensastypratiwiegmail.com \\ ªnggidianti@gmail.com
}

\begin{abstract}
Abstrak- Pertumbuhan dan perkembangan anak meliputi banyak aspek mulai dari perkembangan fisik, perkembangan mental, hingga memiliki kemampuan baru di setiap tahapan usia. Masing-masing anak dapat memiliki laju perkembangan yang berbeda-beda. Namun, ada beberapa hal yang perlu diperhatikan karena bisa jadi menunjukkan adanya gangguan perkembangan, termasuk gejala autisme. Apabila anak autisme tidak mendapat penanganan secara dini, kondisi autis akan menjadi permanen. Oleh karena itu tatalaksana terapi harus dilakukan pada usia sedini mungkin, yaitu dibawah usia 3 tahun. Dalam mendeteksi anak yang menderita autis memang tidak mudah dikarenakan butuh waktu hingga usia dua tahun untuk dapat memastikan anak benar benar mengidap autis. Autis sendiri tidak hanya dapat dideteksi oleh penalaran awam orang tua dari informasi yang didapatnya. Untuk membantu ditahap awal deteksi gangguan autisme pada anak, diperlukannya sebuah metode dalam mendiagnosis gejala yang ditunjukkan anak yaitu fuzzy expert system yang menggunakan metode inferensi fuzzy mamdani.
\end{abstract}

Kata kunci - diagnosis dini, autis, inferensi fuzzy mamdani

\section{Pendahuluan}

Pertumbuhan dan perkembangan anak meliputi banyak aspek mulai dari perkembangan fisik, perkembangan mental, hingga memiliki kemampuan baru di setiap tahapan usia. Kemampuan baru pertahapan usia ini umum disebut sebagai development milestones (misalnya tersenyum, mengucapkan kata pertama, mulai berjalan, atau duduk sendiri tanpa ditopang) serta dapat digunakan oleh orang tua dan dokter untuk mengamati perilaku, kemampuan, dan perkembangan anak[1]. Masing-masing anak dapat memiliki laju perkembangan yang berbeda-beda. Namun, ada beberapa hal yang perlu diperhatikan karena bisa jadi menunjukkan adanya gangguan perkembangan, termasuk gejala autisme.

Gejala autisme sangat bervariasi. Sebagian anak berperilaku hiperaktif dan agresif atau menyakiti diri, tapi ada pula yang pasif. Mereka cenderung sangat sulit mengendalikan emosinya dan sering tempertantrum (menangis dan mengamuk). Kadang-kadang mereka menangis, tertawa atau marah-marah tanpa sebab yang jelas.

Dalam mendeteksi anak yang menderita autis memang tidak mudah dikarenakan butuh waktu hingga usia dua tahun untuk dapat memastikan anak benar benar mengidap autis. Autis sendiri tidak hanya dapat dideteksi oleh penalaran awam orang tua dari informasi yang didapatnya. Oleh karena itu, untuk membantu ditahap awal deteksi gangguan autisme pada anak, dirancanglah perangkat lunak berbasis android sebagai pakar (baik dokter ataupun psikiater) dalam mendiagnosa gejala yang ditunjukkan anak dengan menggunakan metode inferensi fuzzy mamdani.

Logika fuzzy sendiri sering digunakan dalam pemecahan masalah yang menjelaskan sistem bukan melalui angka-angka, melainkan secara linguistik, atau variabel-variabel yang mengandung ketakpastian/ ketidaktegasan. Nilai-nilai yang bersifat tidak pasti ini berdasarkan penalaran yang mengkombinasikan variabel numerik, variabel linguistik, dan aturan-aturan. Adapun perangkat lunak yang digunakan dalam diagnosis ini tersebut berupa sistem pakar yang memiliki pengetahuan layaknya pakar dan proses diagnosa berprosedur yang juga mampu mendiagnosa gejala layaknya pakar.

\section{KAJIAN PUSTAKA}

\section{A. Sistem Pakar}

Sistem pakar adalah aplikasi berbasis komputer yang digunakan untuk menyelesaikan masalah sebagaimana yang dipikirkan oleh pakar. Pakar yang dimaksud di sini adalah orang yang mempunyai keahlian khusus yang dapat menyelesaikan masalah yang tidak dapat diselesaikan oleh orang awam. Sistem pakar dipandang berhasil ketika mampu mengambil keputusan seperti yang dilakukan oleh pakar aslinya baik dari sisi proses pengambilan keputusan maupun hasil keputusan yang diperoleh[2]

\section{B. Logika Fuzzy}

Logika fuzzy adalah suatu cara yang tepat untuk memetakan suatu ruang input ke dalam suatu ruang output [3]. Bojadziev G. dan Bojadziev M. (2007) menyatakan 
bahwa logika fuzzy adalah perluasan dari banyaknya nilai logika di dalam arti dari pembentukan fuzzy set dan fuzzy relation sebagai tool menjadi sistem yang banyak nilai logika [4].

\section{Sistem Inferensi Fuzzy}

Sistem Inferensi Fuzzy (Fuzzy Inference System / FIS) disebut juga fuzzy inference engine adalah sistem yang dapat melakukan penalaran dengan prinsip serupa seperti manusia melakukan penalaran dengan nalurinya. Sistem Inferensi Fuzzy dapat dilakukan dengan tiga metode yaitu metode Tsukamoto, metode Mamdani dan metode Sugeno. Dalam penelitian ini metode yang digunakan adalah metode Mamdani. Metode ini diperkenalkan oleh Ebrahim Mamdani pada tahun 1975. Metode Mamdani sering juga dikenal dengan metode $\operatorname{Max}-\operatorname{Min}[3]$.

\section{Fuzzy Mamdani}

Pada metode Mamdani, terdapat 4 tahap untuk mendapatkan output, yaitu:

1. Fuzzyfication, pada tahap pertama ini, nilai input yang berupa nilai crisp akan dikonversikan menjadi nilai fuzzy, sehingga dapat dikelompokkan pada himpunan fuzzy tertentu. Tahap ini juga menentukan himpunan fuzzy untuk output.

2. Rule Evaluation, langkah kedua adalah mengambil nilai input yang telah difuzzifikasikan dan mengaplikasikan ke dalam antecedents pada aturanaturan fuzzy lalu diimplikasikan. Fungsi implikasi yang digunakan adalah Min.

3. Rule Aggregation, adalah proses dari penggabungan nilai keluaran dari semua aturan. Pada tahap ini, digunakan metode Max, dimana solusi himpunan fuzzy diperoleh dengan cara mengambil nilai maksimum aturan, yang kemudian digunakan untuk memodifikasi daerah fuzzy.

4. Defuzzification, langkah terakhir dari proses inferensi fuzzy adalah untuk mengkonversi nilai fuzzy hasil dari aggregasi aturan ke dalam sebuah bilangan crisp. [5]

$$
\operatorname{COG}=\frac{\sum_{x=a}^{b} \mu_{A}(x) x}{\sum_{x=a}^{b} \mu_{A}(x)}
$$

\section{E. Autisme}

Pada awalnya istilah "autisme" diambilnya dari gangguan schizophrenia, dimana Bleuer memakai autisme ini untuk menggambarkan perilaku pasien skizofrenia yang menarik diri dari dunia luar dan menciptakan dunia fantasinya sendiri. Namun ada perbedaan yang jelas antara penyebab dari autisme pada penderita skizofrenia dengan penyandang autisme infantile. Pada skizofrenia, autisme disebabkan dampak area gangguan jiwa yang didalamnya terkandung halusinasi dan delusi yang berlangsung minimal selama 1 bulan, sedangkan pada anak-anak dengan autisme infantile terdapat kegagalan dalam perkembangan yang tergolong dalam kriteria gangguan pervasif dengan kehidupan autistik yang tidak disertai dengan halusinasi dan delusi[6].

\section{METODOLOGI PENELITIAN}

\section{A. Diagram Alir Penelitian}

Diagram alir penelitian merupakan sebuah diagram dengan simbol-simbol grafis yang menyatakan aliran algoritma atau proses yang menampilkan langkah-langkah penelitian yang disimbolkan dalam bentuk kotak, beserta urutannya dengan menghubungkan masing-masing langkah tersebut menggunakan tanda panah.

Langkah-langkah yang dilakukan dalam penelitian:

\section{Tahap Penelitian dan Pengumpulan Informasi}

a. Studi Literatur

Studi literatur dilakukan dengan mencari referensi ilmu pengetahuan yang berhubungan dengan sistem yang akan dibuat seperti referensi UML (Unified Modelling Languange), PHP (PHP: Hypertext Preprocessor), OOP (Object Oriented Programing).

b. Pengumpulan Data

Pengumpulan data dilakukan dengan mencari informasi mengenai gambaran sistem yang ada dan yang akan diterapkan dalam sistem yang akan dirancang serta memperoleh data-data yang diperlukan. Pengumpulan data dilakukan dengan melakukan wawancara dan observasi terhadap sistem yang sedang berjalan.

c. Perancangan Konseptual dan Prototipe Sistem Perancangan konseptual dilakukan dengan beberapa tahapan yaitu perancangan arsitektur sistem, perancangan use case diagaram, perancangan class diagram, perancangan sequence diagram dan perancangan basis data. Kemudian dilanjutkan dengan perancangan prototipe sistem terdiri yang terdiri dari perancangan struktur antarmuka sistem dan perancangan layout dan antarmuka sistem.

d. Pembuatan Sistem

Merupakan implementasi perancangan konseptual dan prototipe sistem kedalam bentuk aplikasi berbasis andorid.

e. Pengujian dan Validasi Sistem

Pengujian dilakukan untuk mengetahui kelayakan sistem yang telah dibuat terhadap kebutuhan sistem dan tujuan pembuatan sistem. Pengujian menggunakan metode uji validitas.

f. Analisis Hasil Pengujian

Analisis dilakukan dalam tahap pengujian dan validasi untuk mengetahui karakteristik sistem yang telah dirancang.

g. Penarikan Kesimpulan 
Gambar 1 menjelaskan langkah-langkah yang dilakukan dalam bentuk bentuk flowchart.

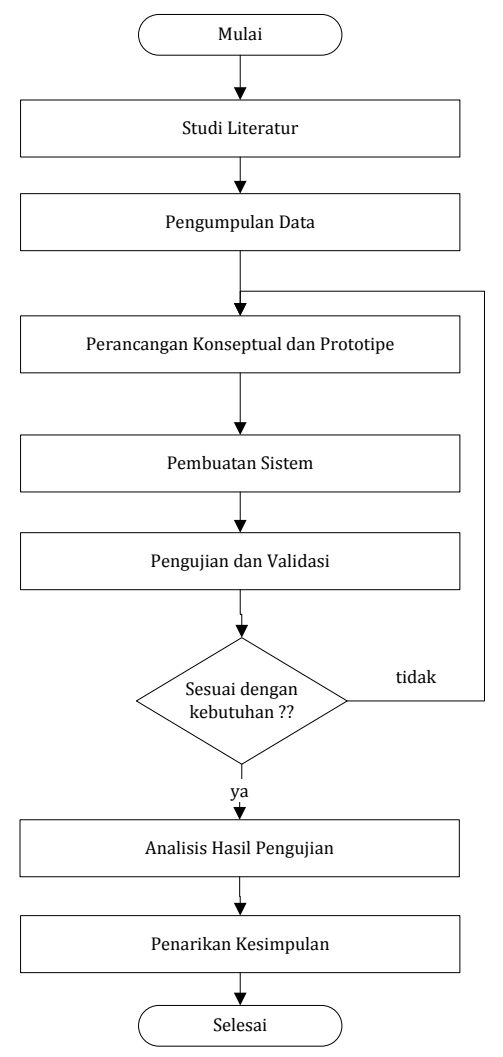

Gambar. 1 Diagram Alir Penelitian

\section{B. Akuisisi Pengetahuan}

Akuisisi pengetahuan ditujukan untuk mengumpulkan informasi/data yang dibutuhkan dalam proses sistem pakar. Adapun data yang didapat berasal dari pakar maupun sumber literatur. Berikut ini merupakan daftar kelompok gejala dalam skala penilaian autisme pada anak, yang ditunjukkan pada Tabel I. Masing-masing kelompok gejala memiliki indikator tingkatan kondisi, yakni "No", "Resolved", "Mild", "Moderate", dan "Severe".

Pada tiga kelompok gejala, masing-masing menaungi beberapa gejala. Kelompok "Kesulitan dalam Interaksi Sosial" dan "Kesulitan dalam Berperilaku" masing-masing menaungi 15 gejala, sedangkan kelompok "Keterlambatan Kemampuan Berbicara dan Berbahasa" menaungi 14 gejala. Gejala-gejala tersebut masing-masing juga memiliki indikator tingkatan kondisi "No", "Resolved", "Mild", "Moderate", dan "Severe".

\section{Pembobotan}

Pada setiap kondisi gejala terdapat lima indikasi opsi kondisi yang masing-masing memiliki bobotnya. Namun dalam penelitian ini, pembobotan opsi indikasi tersebut menggunakan pembobotan Rank Order Centroid (ROC) karena lebih mudah untuk disesuaikan dengan metode Fuzzy Mamdani yang diterapkan.
TABEL I

KELOMPOK GEJALA AUTISME

\begin{tabular}{|c|c|c|c|}
\hline No. & & & Keterangan \\
\hline \multirow[t]{6}{*}{1.} & \multicolumn{2}{|l|}{ Gejala: } & Kesulitan dalam Interaksi Sosial \\
\hline & \multirow[t]{5}{*}{ Indikasi: } & No & $\begin{array}{l}\text { Tidak ada, perkembangan kemampuan dalam } \\
\text { berinteraksi sosial tampak normal }\end{array}$ \\
\hline & & Resolved & $\begin{array}{l}\text { Saat ini memiliki kemampuan sosial yang normal, } \\
\text { namun sebelumnya pernah mengalami salah satu } \\
\text { kondisi di bawah ini. }\end{array}$ \\
\hline & & Mild & $\begin{array}{l}\text { Tampak normal saat berinteraksi dengan orang lain, } \\
\text { namun tampak memiliki sedikit perilaku aneh atau } \\
\text { tidak mampu membaca situasi. Misalnya tidak } \\
\text { memahami situasi dimana bagi orang lain dia } \\
\text { membosankan karena terus menerus membicarakan hal } \\
\text { yang sama. Selain itu, bahkan menganggap dirinya } \\
\text { disukai (saat ia dijadikan bahan gurauan oleh yang } \\
\text { lain). }\end{array}$ \\
\hline & & Moderate & $\begin{array}{l}\text { Memiliki masalah yang tampak jelas dalam } \\
\text { berinteraksi. Tertarik dalam interaksi sosial, tapi } \\
\text { terlihat janggal, sangat pemalu, ataupun aneh. Tampak } \\
\text { berdiri terlalu dekat saat berbincang, menyentuh orang } \\
\text { lain dengan tidak wajar, ataupun berbicara dengan nada } \\
\text { yang tidak sesuai. Anak dengan kondisi ini biasanya } \\
\text { tampak terisolasi dari sosial dan memiliki teman yang } \\
\text { sangat sedikit. }\end{array}$ \\
\hline & & Severe & $\begin{array}{l}\text { Tampak tidak memiliki ketertarikan untuk berinteraksi } \\
\text { dengan orang lain atau terlihat risih/cemas saat berada } \\
\text { di lingkungan sosial. Bagi anak usia 2-3 tahun, perilaku } \\
\text { yang tampak seperti hanya ingin bermain sendiri, } \\
\text { menangis, mengamuk, atau kesal saat berada bersama } \\
\text { dengan anak lainnya. }\end{array}$ \\
\hline \multirow[t]{6}{*}{2.} & \multicolumn{2}{|l|}{ Gejala: } & Keterlambatan Kemampuan Berbicara dan Berbahasa \\
\hline & \multirow[t]{5}{*}{ Indikasi: } & No & $\begin{array}{l}\text { Tidak ada, perkembangan kemampuan berbicara dan } \\
\text { berbahasa tampak normal }\end{array}$ \\
\hline & & Resolved & $\begin{array}{l}\text { Tampak normal, tapi sebelumnya pernah mengalami } \\
\text { salah satu kondisi di bawah ini. }\end{array}$ \\
\hline & & Mild & Mengalami kesulitan dalam pemahaman berbahasa. \\
\hline & & Moderate & $\begin{array}{l}\text { Mengalami keterlambatan dalam perkembangan } \\
\text { berbicara. (Hanya mencapai } 40-70 \% \text { dari tahap } \\
\text { usianya) }\end{array}$ \\
\hline & & Severe & $\begin{array}{l}\text { Tidak menunjukkan adanya kemampuan berbahasa } \\
\text { atau hanya mampu menguasai satu kata. Bagi anak usia } \\
\text { di bawah } 4 \text { tahun, hal ini bisa dievaluasi melalui } \\
\text { penilaian perkembangan oleh tenaga profesional } \\
\text { (dokter anak, psikolog, atau psikiater). }\end{array}$ \\
\hline \multirow[t]{6}{*}{3.} & \multicolumn{2}{|l|}{ Gejala: } & Kesulitan dalam Berperilaku \\
\hline & \multirow[t]{5}{*}{ Indikasi: } & No & $\begin{array}{lcc}\text { Normal, tidak menunjukkan } & \text { adanya } \\
\text { kesulitan/ketidakwajaran dalam berperilaku. }\end{array}$ \\
\hline & & Resolved & $\begin{array}{l}\text { Normal, namun sebelumnya pernah mengalami salah } \\
\text { satu kondisi di bawah ini. }\end{array}$ \\
\hline & & Mild & $\begin{array}{l}\text { Tampak normal, namun kadang mengamuk berlebihan } \\
\text { dan menunjukkan perilaku tidak wajar. }\end{array}$ \\
\hline & & Moderate & $\begin{array}{l}\text { Berperilaku yang berpotensi berbahaya atau } \\
\text { berperilaku mengamuk, namun masih dapat dikontrol } \\
\text { dan diprediksi. }\end{array}$ \\
\hline & & Severe & $\begin{array}{l}\text { Perilaku sangat sulit diatur hingga tidak dapat dibiarkan } \\
\text { sendirian. Bisa saja menjadi sangat liar, di luar kendali, } \\
\text { ataupun menyakiti diri sendiri/orang lain. }\end{array}$ \\
\hline
\end{tabular}

ROC didasarkan pada tingkat kepentingan atau prioritas dari sebuah kriteria. Setiap opsi indikasi gejala (kriteria) yakni No, Resolved, Mild, Moderate, Serve yang ditunjukan pada Tabel II. 
TABEL II

NILAI BOBOT INDIKATOR TINGKATAN KONDISI

\begin{tabular}{|c|c|c|}
\hline $\begin{array}{c}\text { Indikator } \\
\text { Tingkatan } \\
\text { Kondisi }\end{array}$ & Perhitungan Nilai Bobot & $\begin{array}{c}\text { Nilai } \\
\text { Bobot }\end{array}$ \\
\hline No & $W_{N o}=\frac{\left(0+0+0+0+\frac{1}{5}\right)}{5}=\frac{0+0+0+0+0.2}{5}=\frac{0.2}{5}=0.04$ & 0.04 \\
\hline Resolved & $\begin{aligned} W_{\text {Resolved }} & =\frac{\left(0+0+0+\frac{1}{4}+\frac{1}{5}\right)}{5}=\frac{0+0+0+0.25+0.2}{5} \\
& =\frac{0.45}{5}=0.09\end{aligned}$ & 0.09 \\
\hline Mild & $\begin{aligned} W_{\text {Mild }} & =\frac{\left(0+0+\frac{1}{3}+\frac{1}{4}+\frac{1}{5}\right)}{5}=\frac{0+0+0.333+0.25+0.2}{5} \\
& =\frac{0.783}{5}=0.1566\end{aligned}$ & 0.1566 \\
\hline Moderate & $\begin{aligned} W_{\text {Moderate }} & =\frac{\left(0+\frac{1}{2}+\frac{1}{3}+\frac{1}{4}+\frac{1}{5}\right)}{5}=\frac{0+0.5+0.333+0.25+0.2}{5} \\
& =\frac{1.283}{5}=0.2566\end{aligned}$ & 0.2566 \\
\hline Severe & $\begin{aligned} W_{\text {Severe }} & =\frac{\left(1+\frac{1}{2}+\frac{1}{3}+\frac{1}{4}+\frac{1}{5}\right)}{5}=\frac{1+0.5+0.333+0.25+0.2}{5} \\
& =\frac{2.283}{5}=0.4566\end{aligned}$ & 0.4566 \\
\hline
\end{tabular}

\section{Kaidah-kaidah}

Aturan yang diterapkan berupa implikasi "SebabAkibat". Pada Tabel 3 ditunjukkan aturan yang berlaku untuk proses perhitungan. Dari pemetaan yang menghasilkan 64 kemungkinan aturan, hanya 33 aturan yang dapat digunakan dan sesuai dengan logika untuk menentukan golongan ASD.

TABEL III

ATURAN FUZZY PENENTUAN GOLONGAN ASD

\begin{tabular}{|c|c|c|c|c|}
\hline Aturan & KIS & KKBB & KB & GASD \\
\hline [R1] & Normal & Normal & Normal & Normal \\
\hline [R2] & Ringan & Ringan & Ringan & Ringan \\
\hline [R3] & Sedang & Sedang & Sedang & Sedang \\
\hline [R4] & Berat & Berat & Berat & Berat \\
\hline [R5] & Normal & Normal & Ringan & Normal \\
\hline [R6] & Normal & Ringan & Normal & Normal \\
\hline [R7] & Normal & Ringan & Ringan & Ringan \\
\hline [R8] & Normal & Sedang & Ringan & Ringan \\
\hline [R9] & Ringan & Normal & Normal & Normal \\
\hline [R10] & Ringan & Normal & Ringan & Ringan \\
\hline [R11] & Ringan & Normal & Sedang & Ringan \\
\hline [R12] & Ringan & Ringan & Normal & Ringan \\
\hline [R13] & Ringan & Ringan & Sedang & Ringan \\
\hline [R14] & Ringan & Sedang & Normal & Ringan \\
\hline
\end{tabular}

yang diteliti dalam penilitian ini menggunakan data pasien yang terindikasi autis dengan memasukkan gejalagejala yang terlihat. Dalam setiap kondisi gejala yang dimasukkan didapat bobot dari setiap gejala dimana setiap gejala memiliki kelompok masing-masing yang merupakan variabel input bagi sistem perhitungan fuzzy.

Sesuai hasil perhitungan, maka derajat keanggotaan setiap parameter di masing-masing variabel input ditunjukkan oleh Tabel IV.

TABEL IV

DERAJAT KEANGGOTAAN SETIAP PARAMETER VARIABEL INPUT

\begin{tabular}{|r|l|c|c|c|c|}
\hline No. & \multicolumn{1}{|c|}{ Variabel } & $\boldsymbol{\mu N o r m a l}$ & $\boldsymbol{\mu R \text { Ringan }}$ & $\boldsymbol{\mu \text { Sedang }}$ & $\boldsymbol{\mu B e r a t}$ \\
\hline 1 & $\begin{array}{l}\text { Kesulitan dalam } \\
\text { Interaksi Sosial (KIS) }\end{array}$ & 0 & 0.24925 & 0.39494 & 0 \\
\hline 2 & $\begin{array}{l}\text { Keterlambatan } \\
\text { Kemampuan } \\
\text { Berbicara dan } \\
\text { Berbahasa (KKBB) }\end{array}$ & 0 & 0 & 0.683 & 0.1585 \\
\hline 3 & $\begin{array}{l}\text { Kesulitan dalam } \\
\text { Berperilaku (KB) }\end{array}$ & 0 & 0.7779 & 0 & 0 \\
\hline
\end{tabular}


Setelah mendapat nilai derajat keanggotaan, tahap selanjutnya adalah mencari nilai keanggotaan (fire strength) pada setiap kaidah yang telah ditentukan sebelumnya. Nilai keanggotaan ( $\alpha$-predikat) didapatkan dari nilai derajat keanggotaan terkecil (minimum) dari derajat keanggotaan yang digunakan pada sebuah aturan. Berikut ini pencarian $\alpha$-predikat pada 33 aturan yang telah ditetapkan. Hasil dari implikasi terhadap masing-masing aturan akan menunjukkan nilai $\alpha$-predikat. Selanjutnya adalah menghitung nilai komposisi antar aturan dengan menggunakan metode MAX untuk melakukan komposisi antar semua aturan.

$$
\begin{aligned}
& \left(\mathrm{a}_{1}-1,88\right) / 7,3056=0,1585 \AA \mathrm{a}_{1}=3,0379 \\
& \left(\mathrm{a}_{2}-1,88\right) / 7,3056=0,39494 \AA \mathrm{a}_{2}=4,7653
\end{aligned}
$$

Dengan demikian, fungsi keanggotaan untuk hasil komposisi ini adalah :

$$
\mu[z]=\left\{\begin{array}{cc}
0,1585 ; & z \leq 3,0379 \\
\frac{(z-1,88)}{7,3056} ; & 3,0379 \leq p \leq 4,7653 \\
0,39494 ; & p \geq 4,7653
\end{array}\right.
$$

Selanjutnya adalah defuzzy atau biasa disebut dengan penegasan. Penegasan yang digunakan adalah metode centroid. Untuk itu, harus terlebih dahulu menghitung momen untuk setiap daerah

$$
\begin{aligned}
& \text { M1 }=\int_{0}^{3,0379}(0,1585) z d z=0,7314 \\
& \text { M2 }=\int_{3,0379}^{4,7653}\left(\frac{z-1,88}{7,3056}\right) z d z=1,9238 \\
& \text { M3 }=\int_{4,7653}^{21,4602}(0,39494) z d z=86,4587
\end{aligned}
$$

Kemudian dihitung luas dari setiap daerah :

$$
\begin{array}{ll}
\mathrm{A} 1=3,0379 * 0,1585 & =0,481 \\
\mathrm{~A} 2=(0,1585+0,39494) *(4,7653-3,0379) / 2 & =0,478 \\
\mathrm{~A} 3=(21,4602-4,7653) * 0,39494 & =6,593
\end{array}
$$

Selanjutnya proses defuzzy atau penegasan untuk memberikan hasil akhir. Ada beberapa metode defuzzifikasi pada komposisi aturan Mamdani. Dalam penilitian ini digunakan Metode Centroid (Composite Moment) dengan cara mengambil titik pusat (z) daerah fuzzy.

$$
\begin{gathered}
z=\frac{0,7314+1,9238+86,4587}{0,481+0,478+6,593} \\
=11,8
\end{gathered}
$$

Dari hasil defuzzifikasi, didapatkan nilai akhir $\mathrm{z}$ adalah 11,8 yang termasuk dalam parameter Berat. Berdasarkan dari ujicoba perhitungan terhadap kondisi gejala, didapat hasil yang sedikit berbeda tetapi dalam range yang sama.

\section{KESIMPULAN}

Berdasarkan hasil analisis dan pengujian terhadap Diagnosis Dini Autis Pada Anak Menggunakan Metode Inferensi Fuzzy Mamdani, maka dapat disimpulkan bahwa:

1. Metode dapat diterapkan pada diagnosis secara dini mengenai autis pada anak

2. Berdasarkan hasil pengujian ditemukan beberapa kesamaan hasil terhadap diagnosis secara langsung oleh pakarReferensi

\section{REFERENSI}

[1] Detect Autism Early. 2014. Division of Birth Defects, National Center on Birth Defects and Developmental Disabilities, Centers for Disease Control and Prevention.

[2] Kusrini. 2008. Aplikasi Sistem Pakar Menentukan Faktor Kepastian Pengguna dengan Metode Kuantifikasi Pertanyaan. Yogyakarta: ANDI.

[3] Kusumadewi, S. dan Purnomo, H., 2004, Aplikasi Logika Fuzzy: Untuk Pendukung Keputusan, Graha Ilmu, Yogyakarta.

[4] Bojadziev G, Bojadziev M., 2007, Fuzzy logic for Business, Finance,

and Management second edition, Word Scientific, Singapore.

[5] Kusumadewi, S 2003, Artificial Intelegence (Teknik dan Aplikasinya), Graha Ilmu, Yogyakarta

[6] APA. DSM IV. Diagnostic and Statistical Manual of Mental Disorder, Fourth Edition. Washington DC. 